\title{
A Single-Phase Type-Boost Integrated Inverter for Photovoltaic Applications
}

\author{
Tan-Tai Tran, Minh-Khai Nguyen, Seong-Ha Oh, Pil-Ju Ko, and Geum-Bae Cho
}

\begin{abstract}
Photovoltaic, fuel cell, and wind energy are renewable energy sources that generate their power at very low voltage. Therefore, the distributed generation (DG) systems are powered by micro sources such as fuel cells, photovoltaic and wind energy are unsuitable for grid connection directly without transformer. Therefore, this paper proposes a single phase type-boost integrated inverter (TBII) that merges a dc-dc boost converter and a dc-ac inverter in a single-stage. In the inverter, one of the H-bridge legs is shared with a boost converter. AC output voltage of the inverter can be higher than the de source voltage. This paper shows the operating principles and analysis of the single phase type boost integrated inverter. Also, A pulse width modulation strategy is shown to control the inverter. Simulation results by PSIM software are shown to verify the operating principle of the inverter.
\end{abstract}

Index Terms-H-bridge inverter, dc-dc boost converter, single stage dc-ac converter, photovoltaic system.

\section{INTRODUCTION}

Perhaps no subject in the contemporary society is as attractive as the matter of energy crisis. Therefore, the use of renewable energy sources is good solutions. Renewable energy has some advantages i.e. its pollution free and cheaper However, most renewable energy sources produce a DC power output. An inverter is used for converting the DC electric energy from the renewable energy source into AC electric energy. The inverters are either stand alone or grid connected. In case of grid-connected inverter, the output voltage and frequency of the inverter have to be the same as that of the voltage and frequency of grid.

High-performance voltage-source inverters (VSIs) are widely used in various applications such as AC motor drives, uninterruptible power supplies (UPSs), distributed power systems, and hybrid electric vehicles [1], [2]. However, the traditional voltage source inverters are buck DC-AC power conversion, where the total DC source voltages are higher than the peak AC output voltage.

For fuel cell and Photovoltaic applications where a low input voltage is inverted to a high AC output voltage, an additional DC-DC boost converter [3]-[9] is needed to obtain a desired $\mathrm{AC}$ output. The additional power converter performs two-stage power conversion with high cost and low efficiency. The existing inverter topologies which can be used as boost type inverter have the following drawbacks: (a) high

Manuscript received October 20, 2016; revised June 12, 2017

Tan-Tai Tran, Minh-Khai Nguyen, Seong-Ha Oh, Pil-Ju Ko, and Geum-Bae Cho are with Department of Electrical Engineering, Chosun University, Gwangju, Korea (e-mail: Trantantaikdd@gmail.com, nmkhai00@gmail.com,gbcho@chosun.ac.kr). switch count ( $\geq 5)$ [10]-[12], and (b) complex control [13], [14].

In order to overcome the aforementioned drawbacks of these inverters, this paper proposes a new topology of a boost inverter. Because this new topology is derived by integrating a dc-dc boost converter with a dc-ac inverter, the proposed inverter is termed as a single phase type-boost integrated inverter (TBII). The proposed TBII requires only four controllable switches, one diode, one dc-link capacitor, and one inductor. The proposed inverter is applicable to fuel cells or photovoltaic applications where a low input voltage must be inverted to a high AC output voltage. Therefore, it is suitable for grid connection directly without using transformer. Grid synchronization algorithm is of great importance in control of grid connected power inverter as Hasty and accurate detection of grid voltage parameters such as amplitude, phase and frequency is crucial in order to execute stable control strategies for the interconnection of grid with renewable energy. The operating principles and analysis of the single-phase type-boost integrated inverter is presented. Also, a control strategy for the proposed system is shown. Simulation results are shown to verify the operating principle of the proposed inverter.

\section{SingLe-Phase TyPe-Boost InTEgRATEd INVERTER}

Fig. 1 illustrates a conventional topology for the renewable energy generation system, such as the fuel cell, when the minimum input dc voltage is less than the peak voltage of the utility grid. The former-stage boost converter is composed of MOSFET $\mathrm{S}_{0}$, boost inductor $\mathrm{L}_{1}$, and capacitors $\mathrm{C}_{1}$. Diode $\mathrm{D}_{\mathrm{a}}$ can prevent the current from flowing back into the fuel cell. The grid-connected inverter is composed of MOSFET $\mathrm{S}_{1}-\mathrm{S}_{4}$. The advantage of this topology is that the boost converter and the inverter are operated separately and the controller design is easy. However, a two-stage structure leads to low efficiency.

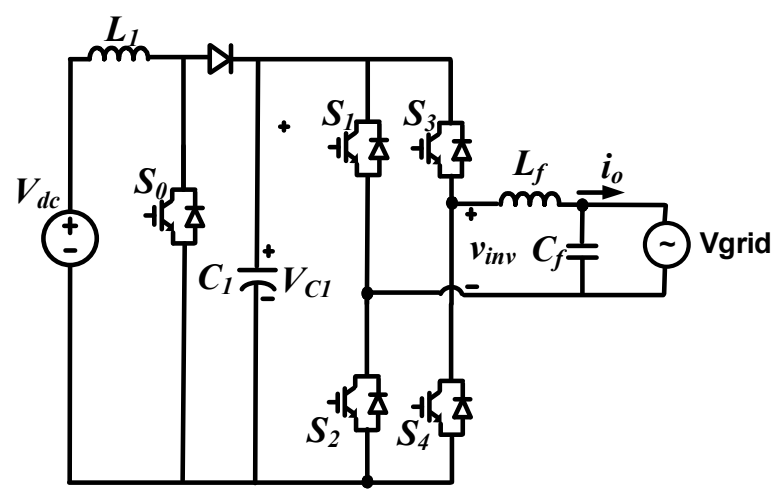

Fig. 1. Construction of conventional two-stage inverter topology. 
The configuration of the single-phase type boost integrated inverter is illustrated in Fig. 2. As shown in Fig. 2, one of the $\mathrm{H}$-bridge legs is shared with a boost converte. Therefore, the proposed system consists of one DC sources, four active switches, one diode, one dc-link capacitor, one inductor, two capacitor filters and an inductor filter connected to the load.

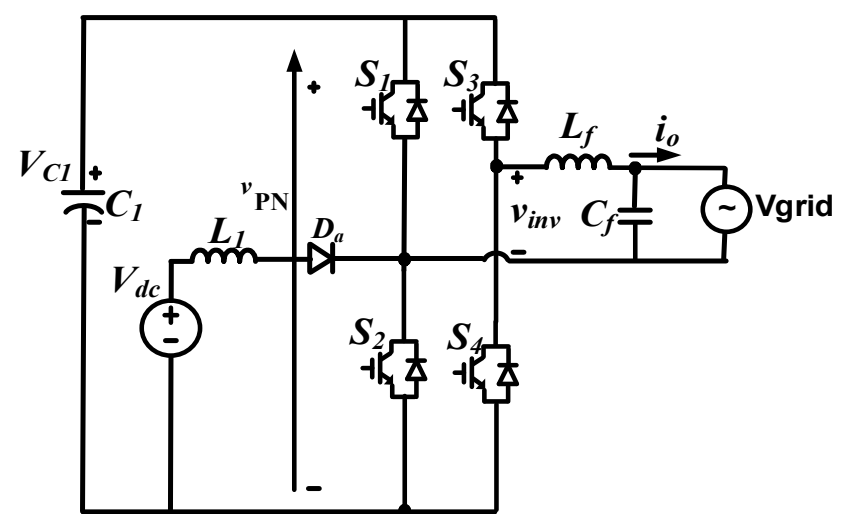

Fig. 2. Construction of single-phase type boost integrated inverter topology.

In shoot-through sate, as shown in Fig. 3(a), the time interval in this state is $D . T$, where $D$ is the duty ratio of switch $\mathrm{S}_{2}$ of each cycle; $T$ is a switching period.

$$
D=1-M \cdot \sin 100 \pi t \text {. }
$$

where $\mathrm{M}$ is the modulation index of the bridge inverter.

During the shoot-through state, $S_{2}$ and diode $D_{a}$ are turned on, while $S_{l}$ are turned off. The capacitor is discharged, while inductor stores energy. We obtain:

$$
L_{1} \frac{d i_{L_{1}}}{d t}=V_{d c} .
$$

In shoot-through sate, as shown in Fig. 3(b), during the shoot-through state, $S_{l}$ and diode $D_{a}$ are turned on, while $S_{2}$ are turned off. The capacitor is charged from $V_{d c}$, while the inductor transfers energy from the DC voltage source to the main circuit. We obtain:

$$
L_{1} \frac{d i_{L_{1}}}{d t}=V_{C 1}-V_{d c} .
$$

Applying the volt-second balance principle to $L_{I}$ in steady state, (1) and (2) yield:

$$
V_{C 1}=\frac{V_{d c}}{1-D} .
$$

The DC-link voltage that crosses the inverter is expressed as:

$$
V_{P N}=V_{C 1}=\frac{V_{d c}}{1-D}
$$

The boost factor of the inverter is defined by:

$$
B=\frac{V_{P N}}{V_{d c}}=\frac{1}{1-D} .
$$

Fig. 4 shows a sinusoidal pulse width modulation strategy for the inverter. With the modulation in Fig. 4, two control waveforms, $V_{\text {control }}$ and $-V_{\text {control }}$ are compared to a high frequency triangle waveform, $V_{t r i}$, to generate control signals for $\mathrm{H}$-bridge switches. The output voltage of inverter is a 3-level: $-\mathrm{V}_{\mathrm{PN}}, 0$ and $\mathrm{V}_{\mathrm{PN}}$.

The peak value of the output voltage is given by:

$$
V_{o}=M \cdot V_{P N} .
$$

where $\mathrm{M}$ is the modulation index of the bridge inverter From (6) and (7), we obtain:

$$
V_{o}=M \cdot \mathrm{B} \cdot V_{d c} .
$$

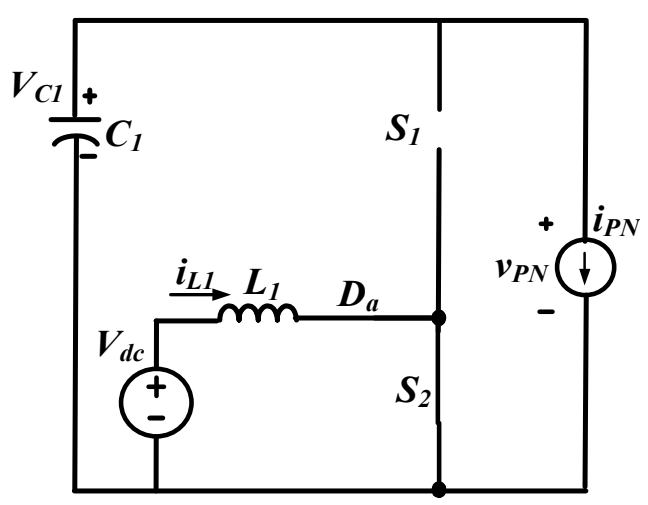

(a)

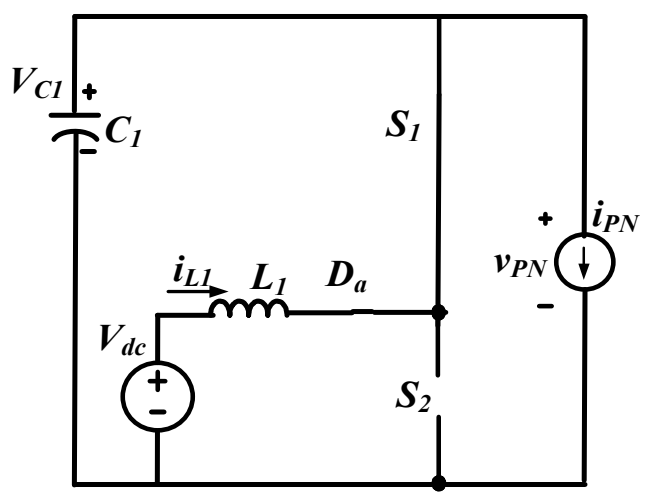

(b)

Fig. 3. Operating states of TBII; (a). shoot-through, and (b). non-shoot-through.

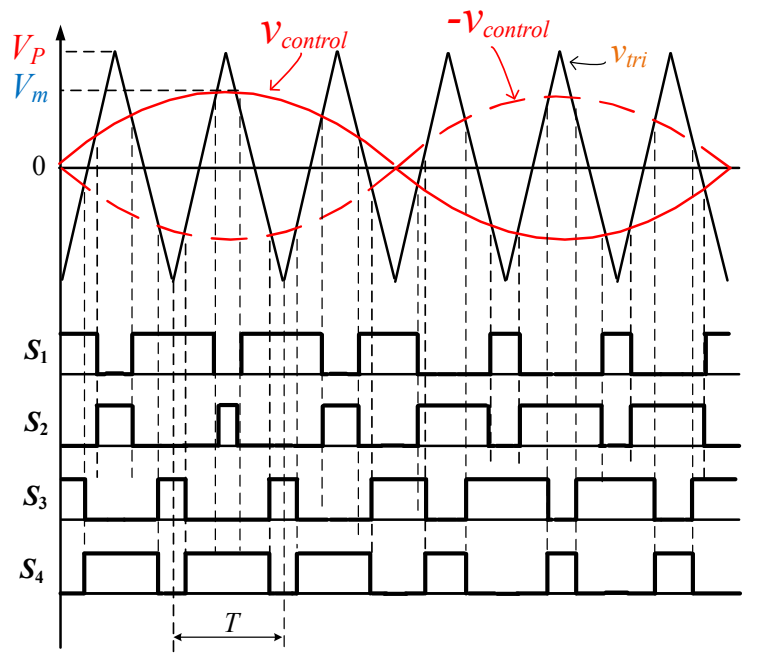

Fig. 4. PWM strategy for the inverter. 


\section{CONTROL SYSTEM ALGORITHM FOR GRID CONNECTION}

To deliver energy to the grid, the phase and frequency of the inverter have to equal those of the grid. Therefore, a grid synchronization method is required. The objective the synchronization algorithm is to get the phase angle of the grid voltage. The synchronization methods should respond immediately to changes in the utility grid. Furthermore, they must have the ability to reject noise and the higher order harmonics. Many synchronization methods have been to get the phase angle of the grid voltage such as zero crossing detection [15], phase-locked loop (PLL) [16]-[19]. A phase locked loop is a closed loop system in which an internal oscillator is controlled to keep the time and phase of an external periodical signal using a feedback loop. The PLL as shown in Fig. 5 is simply a servo system that controls the phase of its output signal such that the phase error between the output phase and the reference phase is the minimum. The quality of the lock directly affects the performance of the control loop in grid tied applications. The PLL can successfully detect the phase angle of the grid voltage even in the presence of noise or higher order harmonics in the grid.

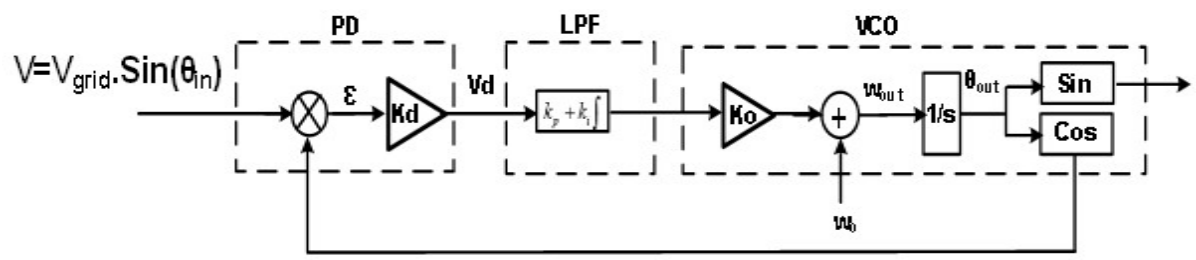

Fig. 5. Phase locked loop basic structure.

\section{Simulation Results}

In order to verify the operating principle of the TBII as shown in Fig. 2, PSIM simulation is used. Table I provides a list of the simulation parameters for the single-phase type boost integrated inverter.

The input DC voltage is set to $96 \mathrm{~V}$ in the inverter in order to test properties of inverter.

\section{TABLE I: PARAMETERS OF THE INVERTER}

\begin{tabular}{cc}
\hline \hline Parameter & Value \\
\hline Output voltage & $220 \mathrm{Vrms}$ \\
\hline Grid voltage & $220 \mathrm{Vrms}$ \\
\hline Output frequency & $50 \mathrm{~Hz}$ \\
\hline Inductors $\left(L_{I}\right)$ & $1 \mathrm{mH}$ \\
\hline Capacitors $\left(C_{l}\right)$ & $1000 \mu \mathrm{F}$ \\
\hline Filter inductor $\left(L_{f}\right)$ & $3 \mathrm{mH}$ \\
\hline Filter Capacitors $\left(C_{\mathrm{f}}\right)$ & $10 \mu \mathrm{F}$ \\
\hline Resistive load $(R)$ & $40 \Omega$ \\
\hline Switching frequency & $10 \mathrm{KHz}$ \\
\hline
\end{tabular}

Fig. 6 and Fig. 7 illustrate the simulation results for the TBII without using PLL.

From Fig. 6(a) and (b), we can see that the output voltage of the inverter is $220 \mathrm{Vrms}$ with 3-level. The AC output current is 5.4 Arms as shown in Fig. 6(c). The THD of output voltage with using filter is $1.78 \%$.

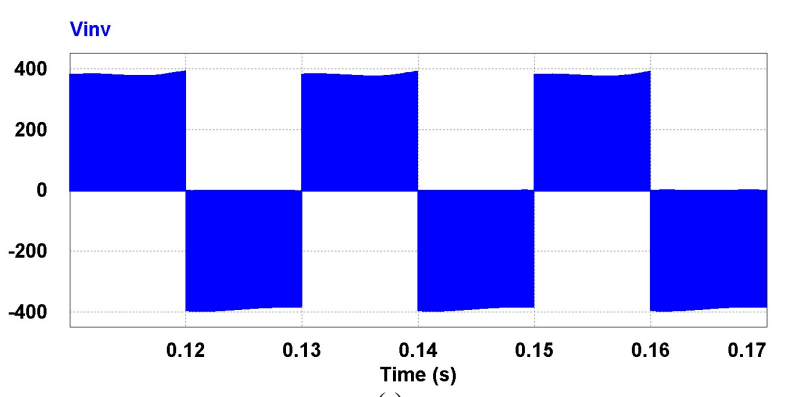

(a)

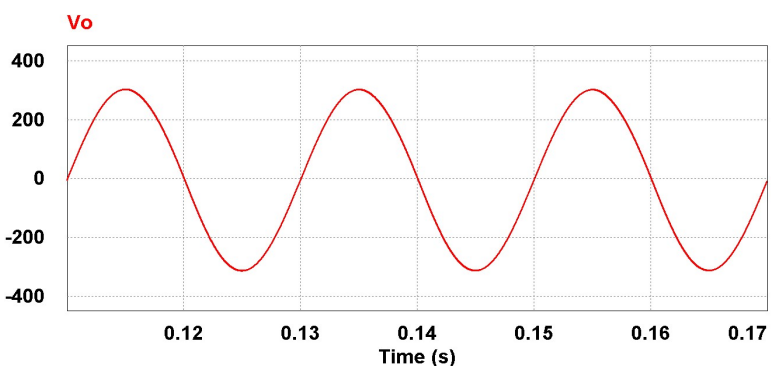

(b)

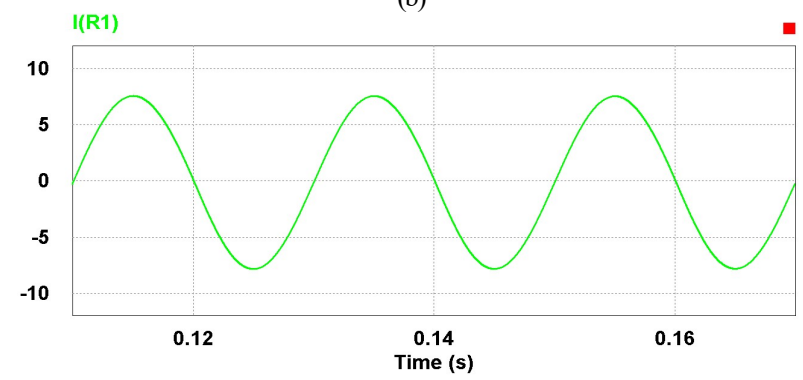

(c)

Fig. 6. Simulation results for the inverter. (a) 3-level output voltage; (b) output voltage with using Filter, output current.

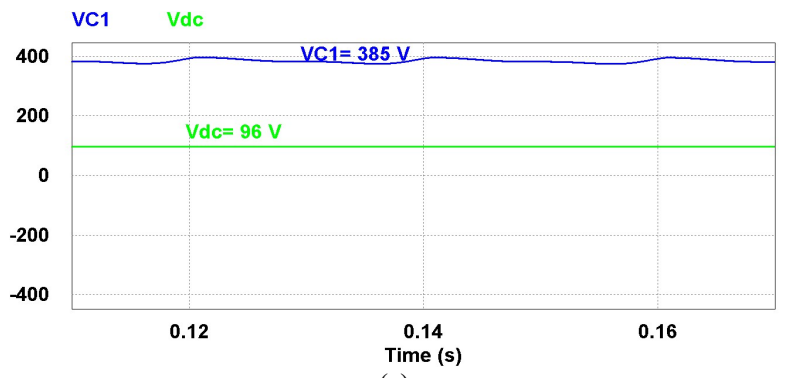

I(L1)

(a)

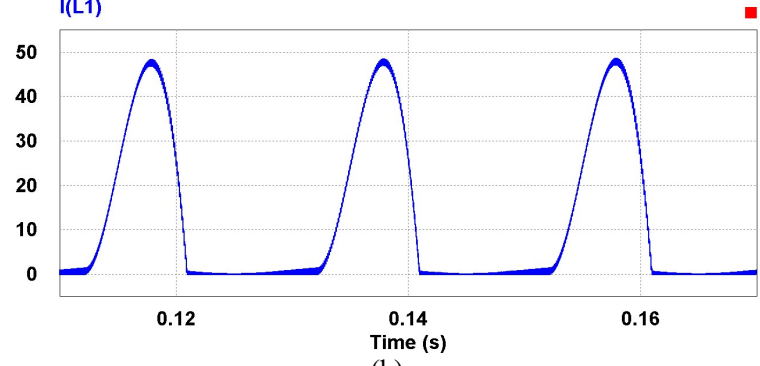

(b)

Fig. 7. Simulation results for the inverter. (a). capacitor voltage $C_{1}$, input voltage $\mathrm{V}_{\mathrm{dc}}$; and (b). input current $\mathrm{i}_{\mathrm{L}}$. 
As shown in Fig. 7(a), we can see that the capacitor voltage $\mathrm{C}_{1}$ is boosted to $385 \mathrm{~V}$. A discontinuous input current with the ripple of input current is 48A as shown in Fig. 7(b). Analysing theory above agrees well with the simulation results.

Fig. 8 and Fig. 9 illustrate the simulation results for the TBII with using PLL.

The simulation result of PLL as shown in Fig. 8 shows that the PLL can successfully extract, without errors, the phase angle of the grid voltages, which allows for synchronization with the grid.

As shown in Fig. 9, phase voltage of grid and phase voltage of the inverter is completely same after $0.28 \mathrm{~s}$.
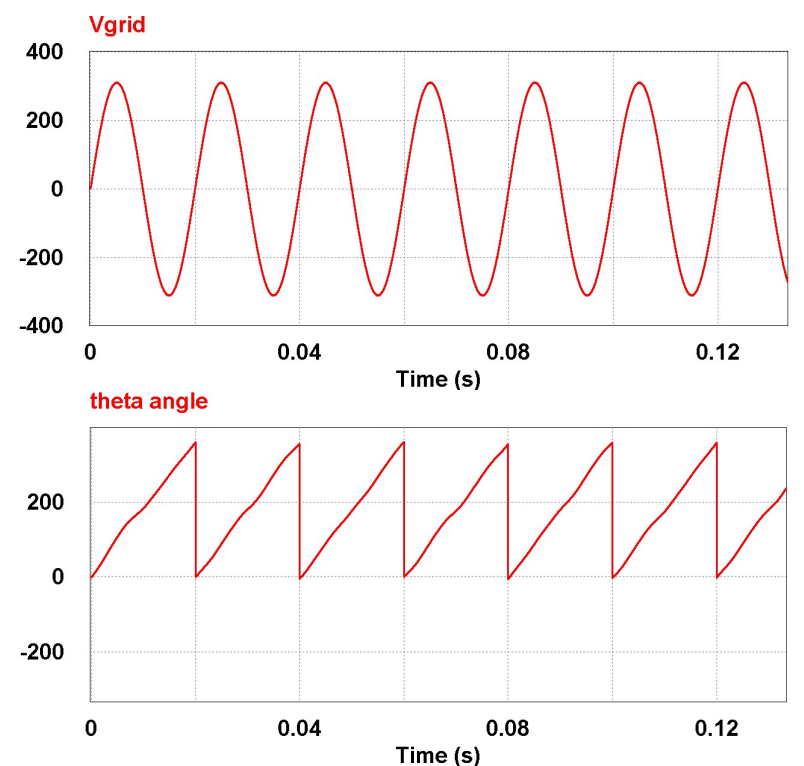

Fig. 8 Simulation results for PLL. From top to bottom: phase voltage of the grid voltage, PLL phase angle.

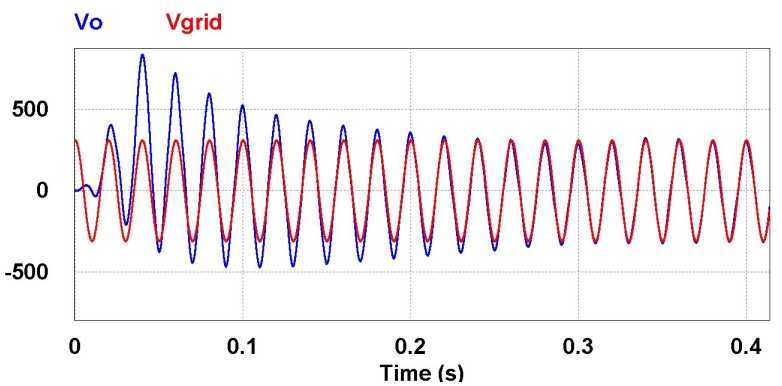

Fig. 9. Grid voltage and output voltage of the inverter with using PLL.

\section{CONCLUSION}

This paper presents the operating principles and analysis of the a single phase type boost integrated inverter. In the inverter, one of the H-bridge legs is shared with a boost converter. The TBII requires only four controllable switches, one diode, one dc-link capacitor, and one inductor. Also, A pulse width modulation strategy is shown to control the inverter. Since ac output voltage of the inverter is higher than source DC input voltage, the inverter suits fuel-cell and PV applications where a low input voltage must be inverted to a high ac output voltage for the microgrid-connected PV power generation. Therefore, it is suitable for grid connection directly without using transformer. Simulation results prove the validity of the PWM technique for controlling the single phase type boost integrated inverter.

\section{ACKNOWLEDGMENTS}

This work was supported by the Korea Institute of Energy Technology Evaluation and Planning (KETEP) and the Ministry of Trade, Industry\& Energy (MOTIE) of the Republic of Korea (NO. 20164010201020).

\section{REFERENCES}

[1] H. Demomi, L. J. Bome, and C. Nayar, "Design and implementation of a low cost sine wave inverter," IEEE - ISIE International Symposium on Industrial Electronics, pp. 280-285, 2003.

[2] T. Kerekes et al., "Evaluation of three-phase transformerless photovoltaic inverter topologies," IEEE Trans. Power Electron., vol. 24, no. 9, pp. 2202-2211, 2009.

[3] B. K. Soeren, K. P. John and F. Blaabjerg, "A review of single-phase grid-connected inverters for photovoltaic modules," IEEE Transactions on Industry Applications, vol. 41, no. 5, 2005.

[4] F. Schimpf et al., "Grid connected converters for photovoltaic, state of the art, ideas for improvement of transformerless inverters", Nordic Workshop on Power and Industrial Electronics, 2008.

[5] B. Singh, D. T. Shahani, and A. K. Verma, "Neural network controlled grid interfaced solar photovoltaic power generation," IET Power Electron, vol. 7, no. 3, pp. 614-626, 2014.

[6] H. Matsuo, F. Kurokawa, "New solar cell power supply system using a boost type bidirectinal dc-dc converter," IEEE Trans. Ind. Electron, vol. 31, no. 1, pp. 1118-1126, 1984.

[7] Y. M. Chen, Y. C. Liu, F. Y. Wu, "Multi-input de/dc converter based on the multiwinding transformer for renewable energy applications," IEEE Trans. Ind. Appl., vol. 38, no. 4, pp. 1096-1104, 2002.

[8] W. Hu, H. Wu, Y. Xing et al., "A full-bridge three-port converter for renewable energy application," in Proc. IEEE Applied Power Electron. Conf., 2014, pp. 57-62.

[9] C. Zhao et al., "An isolated three-port bidirectional dc-dc converter with decoupled power flow management," IEEE Trans. Power Electron., vol. 23, no. 5, pp. 2443-2453, 2008.

[10] N. M. Khai, L. V. Tuan, P. J. Sung et al., "Class of high boost inverters based on switched-inductor structure," IET Power Electron., vol. 8, no. 5, pp. 750-759, 2015.

[11] O. Husev, C. C. Roncero, C. E. Romero et al., "Single phase three-level neutral-point-clamped quasi-Z-source inverter," IET Power Electron, vol. 8, no. 1, pp. 1-10, 2015.

[12] S. S. Nag, S. Mishra, "Current-fed switched inverter," IEEE Trans. Ind. Electron., vol. 61, no. 9, pp. 4680-4690, 2014.

[13] H. Ribeiro, B. Borges, A. Pinto: "Single-stage DC-AC converter for photovoltaic systems," Proc. IEEE Energy Conversion Congress and Exposition, pp. 604-610, 2010.

[14] F. Z. Peng, "Z-source inverter", IEEE Trans. Ind. Appl., vol. 39, no. 2, pp. 504-510, 2003.

[15] A. R. Nasrudin, K. Chaniago, and J. Selvaraj, "Single-phase seven-level grid-connected inverter for photovoltaic system," IEEE Trans. Ind. Electron., vol. 58, no. 6, June 2011.

[16] J. W. Choi, Y. K. Kim, and H. G. Kim, "Digital PLL control for singlephase photovoltaic system," IEE Proceedings-Electric Power Applications, vol. 153, no. 1, pp. 40-46, Jan. 2006.

[17] M. A. Perez, J. R. Espinoza, L. A. Moran, M. A. Torres, and E. A. Araya, "A robust phase-locked loop algorithm to synchronize staticpower converters with polluted ac systems," IEEE Trans. Ind. Electron., vol. 55, no. 5, pp. 2185-2192, May 2008.

[18] Q. Zhang, X. D. Sun, Y. R. Zhong, M. Matsui, and B. Y. Ren, "Analysis and design of a digital phase locked loop for single-phase grid-connected power conversion systems," Industrial Electronics, IEEE Transactions on, vol.58, no. 8, pp. 3581-3592, Aug. 2011.

[19] L. G. B. Rolim et al., "Analysis and software implementation of a robust synchronizing PLL circuit based on the pq theory," IEEE Trans. Ind. Electron., vol. 53, no. 6, pp. 1919-1926, Dec. 2006.

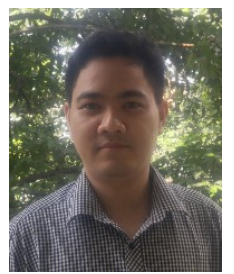

Tan-Tai Tran received the B.Eng. and M.Eng. degrees from Ho Chi Minh University of Technology and Education, Ho Chi Minh City, Vietnam, in 2012 and 2016, respectively, all in electronics engineering. His current research interests include renewable energy systems, automation systems, dc-dc converters and dc-ac inverters. 


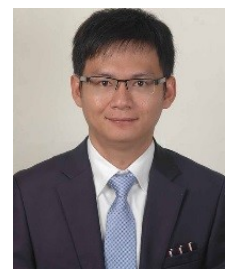

Minh-Khai Nguyen received the B.S. degree in electrical engineering from Ho Chi Minh University of Technology, Ho Chi Minh city, Vietnam, in 2005, and the M.S. and Ph.D. degrees in electrical engineering from Chonnam National University, Korea, in 2007 and 2010, respectively. From 2010 to 2013, he was a lecturer with Nguyen Tat Thanh University, Ho Chi Minh city, Viet Nam. Since 2013, he has been a lecturer with Ho Chi Minh City University of Technology and Education, Ho Chi Minh city, Viet Nam. In 2011-2012, he was a visiting researcher with the Robot Research Initiative Center, Chonnam National University, Korea. His current research interests include renewable energy systems, power quality and power converters.

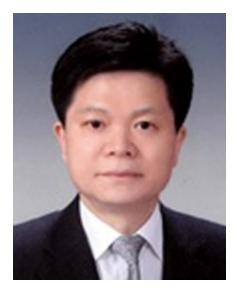

Geum Bae Cho was born in Chonnam, Korea, in 1954. He received the B.S. and M.S degrees in electrical engineering from Chosun University, Gwangju, Korea, in 1980 and 1982, respectively, and $\mathrm{Ph}$. D. degree from Kunkuk University, Seoul, Korea, in 1995. Since 1985, he has been a Professor in the Department of Electrical Engineering, Chosun University, Korea, where he was the Dean of Chosun University College of Engineering. He has authored or coauthored more than 100 published technical papers. His research interests include power electronics, analysis and control of motor, power converter for photovoltaic power system. Prof. Cho was the Vice President of Korea Institute of Power Electronics in 2008. He has been engaged with various academic societies, such as the KIPE, the Korean Institute of Electrical Engineers, and the The Korean Solar Energy Society, Korea.

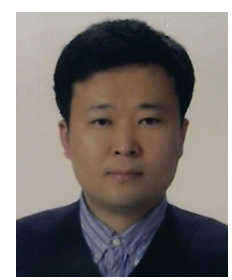

Pil ju Ko received the Ph.D. degrees in electrical engineering from Tokyo Instituted of Technology, Tokyo, Japan, in 2012. From April 2012 to March 2015, he was a Researcher of (JAPAN) National University cooperation Toyohashi University of Technology. From March 2015 to August 2015, he was an Assistant Professor of (JAPAN) National University cooperation of Electro-Communications. Since September 2015, he was an Assistant Professor at Electrical Engineering Chosun University. His current research interests include renewable energy systems, power quality and power converters

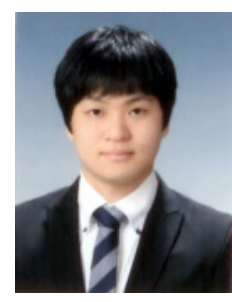

Seongha $\mathrm{Oh}$ received the B.S. and M.S degrees in electrical engineering from Chosun University, Gwangju, Korea, in 2011 and 2014, respectively. From December 2014 to May 2016, he was a Senior Researcher of MPNICS. He is currently working toward the Ph.D. degree in the Department of Electrical Engineering, Chosun University, Gwangju, Korea. His current research interests include converters. renewable energy systems, power quality and power 